\title{
Differences in natural gamma radiation characteristics of Erinpura and Malani granites in NW India
}

\author{
Lars Scharfenberg ${ }^{1, *} \mathbb{D}$, Sebastian Jandausch ${ }^{1}$, Lina Anetzberger $^{1,2}$, \\ Anette Regelous ${ }^{1}$, Kamal K Sharma ${ }^{3}$ and Helga De Wall ${ }^{1}$ \\ ${ }^{1}$ GeoZentrum Nordbayern, Friedrich-Alexander Universität, Schlossgarten 5, 91054 Erlangen, Germany. \\ ${ }^{2}$ Piewak 83 Partner GmbH, Jean-Paul-Straße 30, 95444 Bayreuth, Germany. \\ ${ }^{3}$ Department of Geology, Government Post-Graduate College, Sirohi 307 001, India. \\ ${ }^{*}$ Corresponding author. e-mail: lars.scharfenberg@fau.de
}

MS received 19 August 2018; revised 30 October 2018; accepted 17 January 2019; published online 14 May 2019

In NW India, large volumes of exposed Neoproterozoic basement rocks are formed by two magmatic suites, Erinpura granites as a late thermal event with respect to the $\sim 1$ Ga Delhi Orogeny and the younger Malani igneous suite (770-750 Ma). Average uranium and thorium equivalent concentrations (in ppm) inferred from spectroscopic gamma radiation survey are higher in Malani rocks (Th $47.33 \mathrm{ppm}$ and U $6.95 \mathrm{ppm}$ ) as compared to the Erinpura granites (Th $33.55 \mathrm{ppm}$ and U $4.77 \mathrm{ppm}$ ). These values are considerably above the granite world average (Th $14.8 \pm 13.2 \mathrm{ppm}$; U $3.93 \pm 3.27 \mathrm{ppm}$ ). High U (up to $19 \mathrm{ppm}$ ) and Th (up to $88 \mathrm{ppm}$ ) in some Malani granites and a constant Th-U ratio of 7 points to a high degree of fractionation of the felsic magma. Higher radioelement concentration in the east (Mirpur granite) as compared to the west (Jaswantpura granite) is substantiated by geochemical data. Areas to the west and east of the Sirohi frontal thrust show differences, most likely a consequence of anatexis in the eastern sector. A high linear correlation between inductively coupled plasma mass spectrometry and gamma-ray data underlines the suitability of in-situ measurements for the determination of $\mathrm{U}$ and $\mathrm{Th}$ concentrations during a field survey providing basic information for future petrogenetic and risk-hazard studies in this granitic terrain.

Keywords. Natural gamma radiation; thorium; uranium; granitoids; NW India.

\section{Introduction}

Th and $U$ are trace elements and occur mostly in accessory minerals, like zircon, apatite, monazite, sphene and allanite within igneous and metamorphic rocks (e.g., Wark and Miller 1993; Van Schmus 1995; Marchalland and Fairbridge 1999) and are generally enriched in felsic rocks (e.g., Bea et al.
2003). In contrast, $\mathrm{K}$ is a major element of several rock-forming minerals like feldspar or mica. U, Th and $\mathrm{K}$ are incompatible elements during the melting of mantle rocks; they are, therefore, enriched in the crust but are depleted in the mantle (Vilà et al. 2010). Thus, granites produce a much larger amount of radiogenic heat compared to basalts or peridotites (Menager et al. 1993; Menon et al.

Supplementary material pertaining to this article is available on the Journal of Earth System Science website (http://www. ias.ac.in/Journals/Journal_of_Earth_System_Science). 
2003). Globally, the $\mathrm{Th} / \mathrm{U}$ ratio of the continental crust is about 4 and the $\mathrm{K} / \mathrm{U}$ ratio is about $1 \times 10^{4}$ (Rudnick et al. 1998; McLennan 2001; Jaupart and Mareschal 2003). The major intensity of the natural background radiation on the Earth's surface (effective dose: $2.4 \mathrm{mSv} / \mathrm{yr}$ ) is attributed to radioactive decay chains of the isotopes along with ${ }^{40} \mathrm{~K}$, whereas only a minor part $(0.4 \mathrm{mSv} / \mathrm{yr})$ is attributed to the cosmic radiation dose (IAEA 2004). Due to the small K/U ratio in granites, the radiogenic heat production is mainly controlled by $\mathrm{U}$ and Th concentrations (Rudnick and Fountain 1995; Wedepohl 1995) and U and Th together make up for more than $90 \%$ of the total heat production (Förster and Förster 2000).

Because $\mathrm{U}$ and Th are enriched in felsic magmas, large granitic terrains are under survey for natural gamma radiation (GR) measurements.

Radiogenic heat produced during the decay of the unstable elements can bear potential for geothermal exploration, which is one focus of worldwide studies on granitic terrains (Fernàndez et al. 1998; McLaren et al. 1999; Förster and Förster 2000; Vilà et al. 2010; Scharfenberg et al. 2016). On the other hand, granite exposures are known as regions of enhanced emanation of radiogenic radon gas as products $\left({ }^{222} \mathrm{Rn}\right.$ and $\left.{ }^{220} \mathrm{Rn}\right)$ in the decay chains of $U$ and Th, respectively. Therefore, in countries that use granites frequently as building materials, radioactive decay and related dose of indoor and outdoor radiation is under examination (e.g., Sharaf et al. 1999; Al-Jarallah 2001; Stoulos et al. 2003; Mohanty et al. 2004).

Several methods are used for the survey and mapping of $\mathrm{U}$ and $\mathrm{Th}$ concentrations in natural rock exposures. For larger-scale surveys, airborne gamma ray spectrometer measurements are useful, e.g., for geological mapping (Patra et al. 2016), for radon hazard forecast in Norway (Smethurst et al. 2008) or for establishing heat production maps for granitic terrains (Beamish and Busby 2016). The disadvantages of this method are difficulties in correlation with in-situ data (Beamish and Busby 2016; Scharfenberg and de Wall 2016). In addition, various factors can lead to the inaccuracy of the in-situ data such as topography or weathering (for review, see McCay et al. 2014, and references therein). In contrast, individual data determined by laboratory measurements can provide a very precise analysis of radioelement concentration, but unfortunately with limited control for vast terrains or multiple magma batches. Therefore, in-situ GR measurements, obtained using portable detectors, are useful for field-based studies.

In NW India, large volumes of exposed Neoproterozoic basement rocks are formed by volcanoplutonic units of two magmatic suites (figure 1), which are mined in several quarries for construction material (figure 5c). Both magmatic suites, the Erinpura granites (Coulson 1933; Heron 1953) and the Malani igneous suite (MIS) (Pareek 1984; Bhushan 2000; Sharma 2004) comprise mainly silicic rock types, also described as pink and grey granites and felsic volcanics or dykes (feldspar porphyritic and rhyolith, silicic dykes). So far, only regional and preliminary studies on GR activity of these rock suites are available. A regional study on MIS has categorised the volcano-plutonic rocks as high heat-producing with high radiogenic element concentration (Singh and Vallinayagam 2012). A preliminary study on rock types in the region of Sindreth (figure 1) reports some data on Erinpura granites and the MIS Mirpur intrusion (Scharfenberg et al. 2015). In this study, we provide for the first time, a statistically significant database on radioelement concentration in felsic rocks of NW India in order to show that in-situ GR measurements are valuable data sets for evaluating regional variations in granitic terrains.

During three field campaigns in 2014, 2015 and 2018 , we carried out 277 assays on exposures of felsic igneous rocks, covering a region of ca. $3000 \mathrm{~km}^{2}$ (figure 2). GR is recorded by spectroscopic measurements with a portable spectrometer (RS 230, Radiations Solutions, Canada). For quality control on the precision of the field-based GR measurements, a comparative study with geochemical analysis on selected samples was carried out. The high linear correlation of $\mathrm{Th}$ and $\mathrm{U}$ from inductively coupled plasma mass spectrometry (ICP-MS) data and GR spectroscopy highlights the option of in-situ measurements for discrimination and characterisation of magmatic pulses in granitic terrains.

\section{Geological setting}

Widespread granitic to granodioritic intrusions in the southern domain of the south Delhi fold belt and its western foreland are collectively named the Erinpura granites (Coulson 1933) and considered to form the latest thermal event in the course of the Delhi orogeny (Heron 1953). Erinpura granites comprise coarse-grained, at places porphyritic and fine-grained varieties of biotite, 


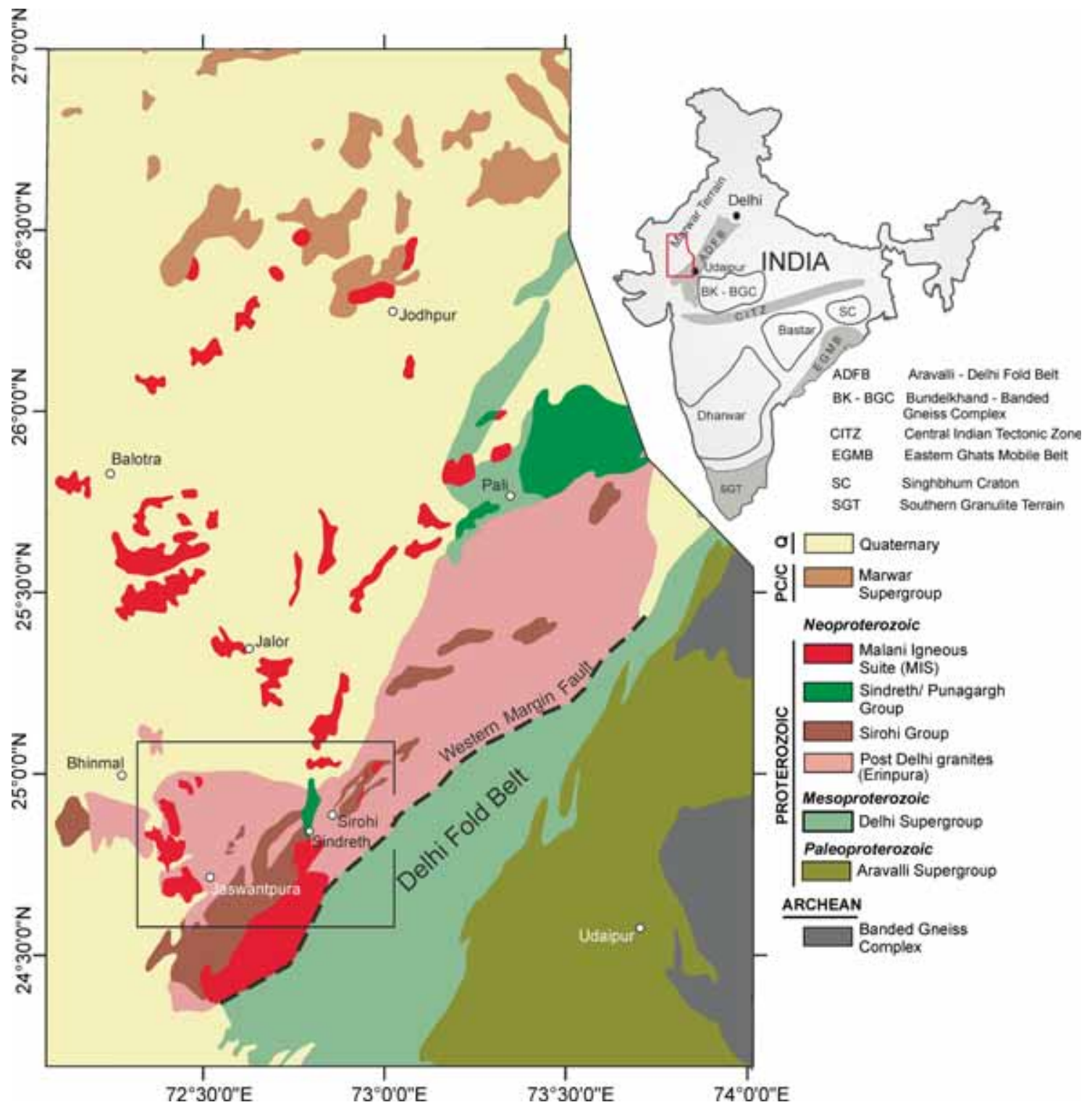

Figure 1. Simplified geological map of the study area (adapted from Gupta et al. 1997). The inset map shows the study area in the context of the cratonic nuclei and Precambrian fold belts in peninsular India. The rectangle marks the study area.

biotite + hornblende and biotite + muscovite granites (figure 3b-d). In the Sirohi fold and thrust belt (de Wall et al. 2014) and in the western foreland of the south Delhi fold belt, granites are sheared (figure 3a), locally with mylonitic to ultramylonitic fabrics (Just et al. 2011). West of the frontal thrust (Sirohi frontal thrust (SFT)) as the limit of this sheared region, the granites show an exclusively magmatic fabric (figure $3 \mathrm{~b}$ ) without any imprint of ductile deformation. These local differences in fabric imprint are considered in figure 2 and marked as Erinpura E and Erinpura W, respectively.

The age range of the Erinpura granites is compiled in figure 4 . The comparison with age data for the MIS (figure 4) (Deb et al. 2001; Konopelko et al. 2007; Gregory et al. 2009; Dharma Rao et al. 2012; Purohit et al. 2012; Arora et al. 2017) supports the model of separate magmatic events. Magmatic rocks of both these age groups have also been identified in Nagarparkar of SE Pakistan (Khan et al. 2012; Jan et al. 2014, 2017), in Madagascar (Archibald et al. 2016) and in South China (Wang et al. 2010; Zhang and Zheng 2013) and have been related to the Neoproterozoic rifting of the continental crust along the periphery of the Rodinia supercontinent ( $\mathrm{Li}$ et al. 2010; de Wall et al. 2018).

In the eastern part of the study area, the younger Malani event is documented in the anatexis of the 


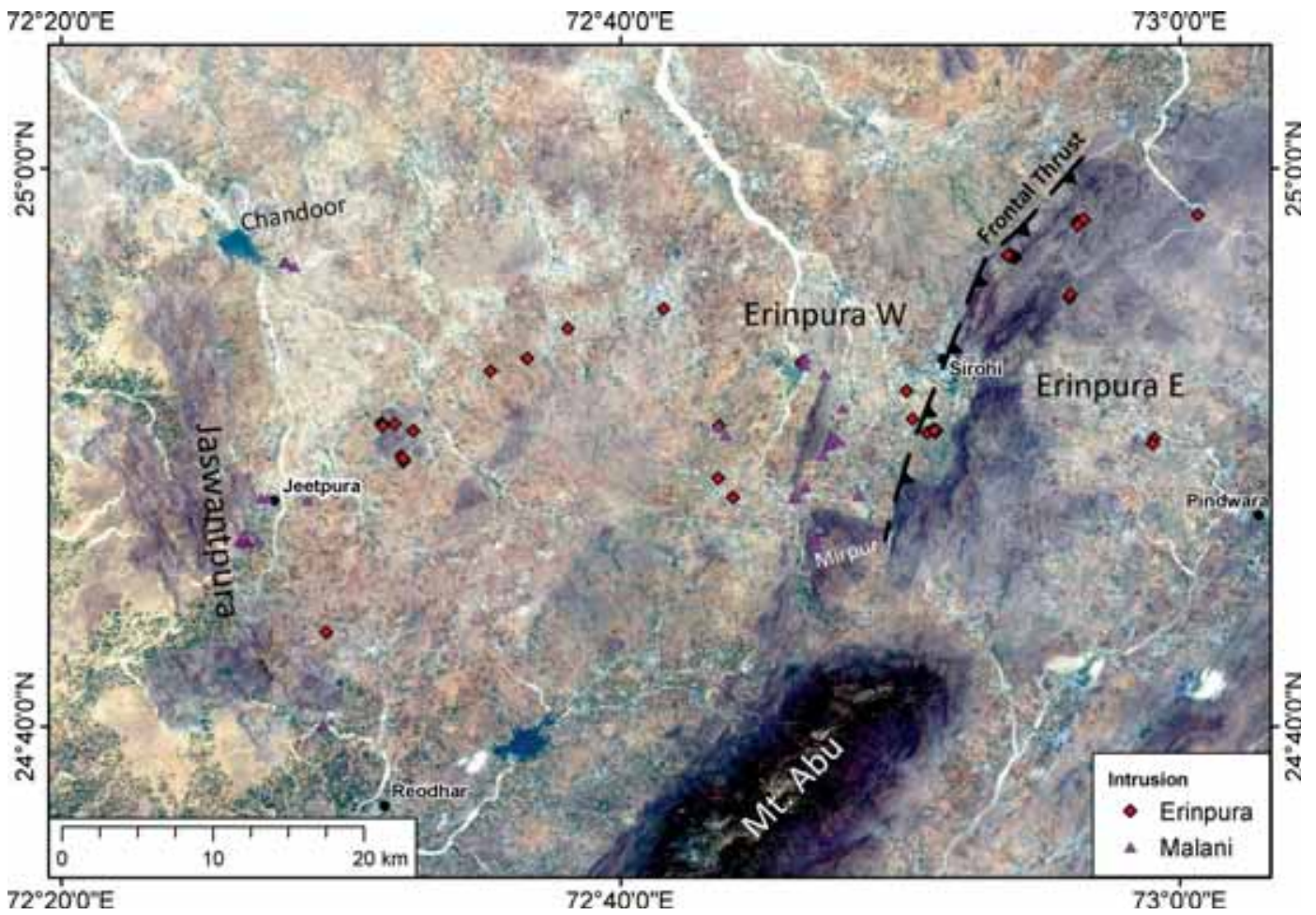

Figure 2. Satellite image of the study area and overview of gamma ray survey locations. For precise assay coordinates, refer the supplementary material. Major granite intrusions are labelled.

Erinpura granites (Just et al. 2011) and synkinematic granite intrusion, e.g., the huge Mt Abu batholith (Ashwal et al. 2013). To the west of the frontal thrust, the Mirpur granite in the eastern sector (de Wall et al. 2010), the Jaswantpura granite (figure 3e) and Chandoor granite (Maheshwari et al. 2002) form intrusions into the undeformed Erinpura basement granites. Furthermore, felsic dykes form individual aligned structures within the Erinpura basement and comprise microgranite, quartz porphyry and feldspar porphyry types (figure 3f). In addition, silicic dykes, composed mainly of quartz and Al-silicates (plagioclase, white mica) are regarded as the most differentiated felsic intrusions. The Malani felsic rocks are at places associated with mafic volcanics, defining bimodal magmatic suites (Schöbel et al. 2017; Wang et al. 2018).

To the west of the SFT, the different magmatic suites are also distinguishable due to their morphological appearance. Most of the region is occupied by the Erinpura granite which forms a peneplain terrain (figure 2) with scattered whale-back-shaped exposures of up to $100 \mathrm{~m}^{2}$ (figure $5 \mathrm{~d}$ ). The younger Malani rocks form prominent topographic heights (figure 5a and b). During our survey in 2014, 2015 and 2018, we obtained 277 measurements from 96 localities in the study area. This comprises 143 measurements on the Erinpura-type granitoids, 55 for Malani granites and 79 on Malani volcanics, respectively.

\section{Methods}

\subsection{Measurements of natural GR}

Surface measurements have been performed, covering the various granite types and some of the typical host rocks. GR was recorded with a portable gamma ray spectrometer RS 230 manufactured by Radiation Solutions, Ontario, Canada. It uses a bismuth germanate (BGO) scintillation detector that, on account of higher material density, is about $50 \%$ more precise than portable units using a sodium iodide (NaI) detector with a detector crystal of the same size. Due to its small size (25 cm long and $10 \mathrm{~cm}$ wide), and lightweight $(2 \mathrm{~kg})$, it is easy to carry and use in the field. Gamma rays cause microscopic light flashes in the BGO scintillation crystal that are transformed into electrical impulses in a photomultiplier tube. These impulses and their strength are registered and counted in the device. During the decay of radioactive elements, characteristic energy peaks are generated. The radiation spectra 

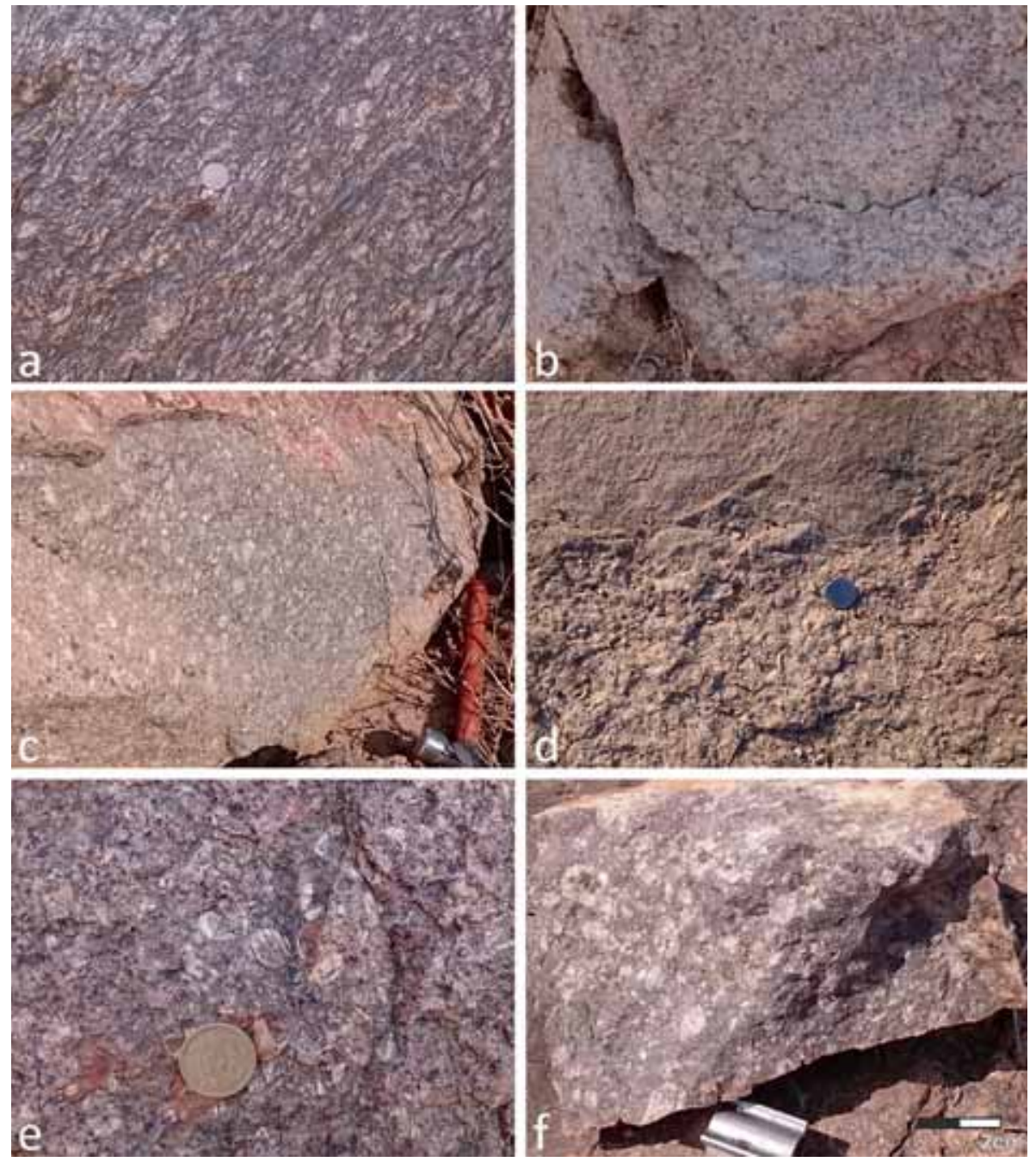

Figure 3. Field appearance of measured Neoproterozoic rocks, fabric varieties of Erinpura granites: (a) Erinpura granite-gneiss E of the SFT; (b) magmatic fabric west of the SFT; (c) porphyritic granite; (d) fine- and coarse-grained. Examples for Malani granites and dykes: (e) Rapakiwi texture in the Jaswantpura biotite-hornblende granite; (f) Malani felsic dyke with porphyric fabric.

are used by the spectrometer to estimate the concentration of radioactive elements. Measurements were taken in the 'assay-mode', using a single measurement for the estimation of thorium (in ppm) and uranium (in ppm) and potassium (wt\%) from the spectrum of GR measured over a certain time interval. In comparison with the scan mode, this type of survey gives a more precise data record. Survey sites were selected to provide a broad coverage of granitoid exposures in the study area. Coordinates of sites for GR measurements were recorded using a GPS connected to the spectrometer via Bluetooth.

A measuring interval of $120 \mathrm{~s}$ was maintained to allow sufficient time to establish a stable spectrum. The device integrates an area of about $1-\mathrm{m}$ diameter with a depth of about $15-25 \mathrm{~cm}$ (depending on material density) when in direct contact with the outcrop. The values used for stripping and background correction were provided by the manufacturer of the device and are stored and applied in the spectrometer unit itself (Radiation Solutions 2009). The manufacturer used concrete pads of $1 \mathrm{~m} \times 1 \mathrm{~m} \times 1 \mathrm{~m}$ size containing known amounts of potassium, uranium and thorium and a fourth pad, with none of these three elements, to measure the background for calibration of the instrument, as described in Grasty et al. (1991). The measurements on the concrete pads are used to obtain the stripping ratios and sensitivity constants for the matrix calculations that are carried out inside the spectrometer for background correction and conversion to ppm (for $\mathrm{U}$ and $\mathrm{Th}$ ) and \% (for potassium). The last measurements described in 


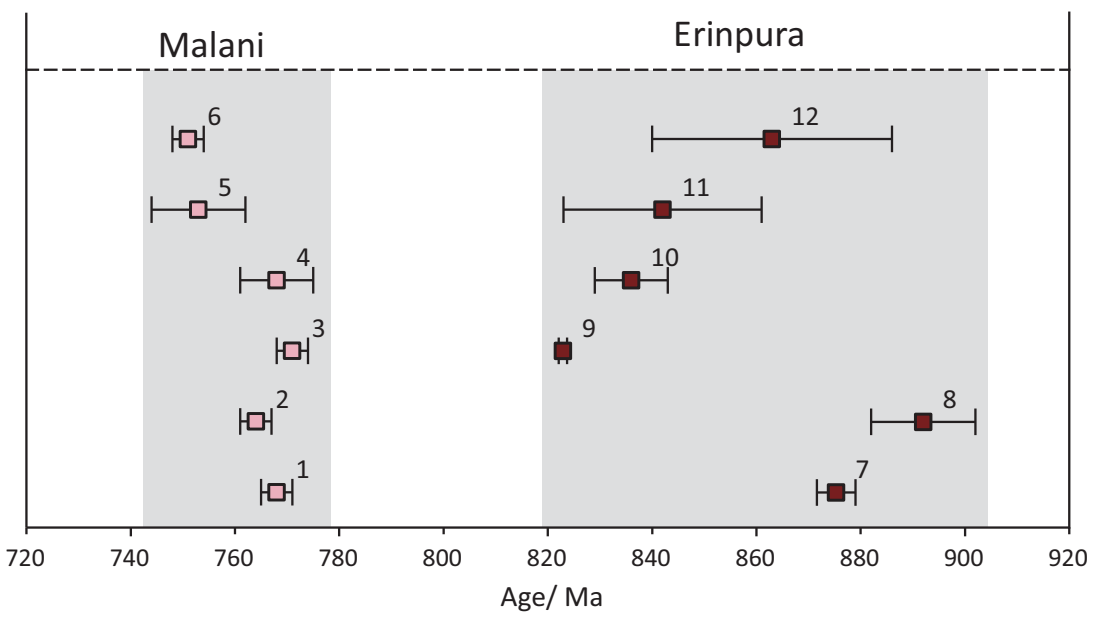

\begin{tabular}{|l|}
\hline 1 Mt. Abu granite-gneisses, Ashwal et al. 2013 \\
2 Mt. Abu pink granite, Ashwal et al. 2013 \\
3 Malani basalt tuff, Gregory et al. 2018 \\
4 Siwaya granite in South Delhi Fold Belt, Deb et al. 2001 \\
5 Synkinematic granite, South Delhi Fold Belt, Singh et al. 2010 \\
6 Magmatic monazite in Erinpura granite gneiss, Just et al. 2011 \\
7 Erinpura type locality, Solanki 2011 \\
8 Erinpura basement granite, Arora et al. 2017 \\
9 Erinpura granite at Jawai Bandh, Purohit et al. 2012 \\
10 Siyawa granite in South Delhi Fold Belt, Deb et al. 2001 \\
11 Synkinematic granite, South Delhi Fold Belt Singh et al. 2010 \\
12 Magmatic monazite in Erinpura granite gneiss, Just et al. 2011 \\
\hline
\end{tabular}

Figure 4. Compilation of age data for the Malani and Erinpura magmatites with references.
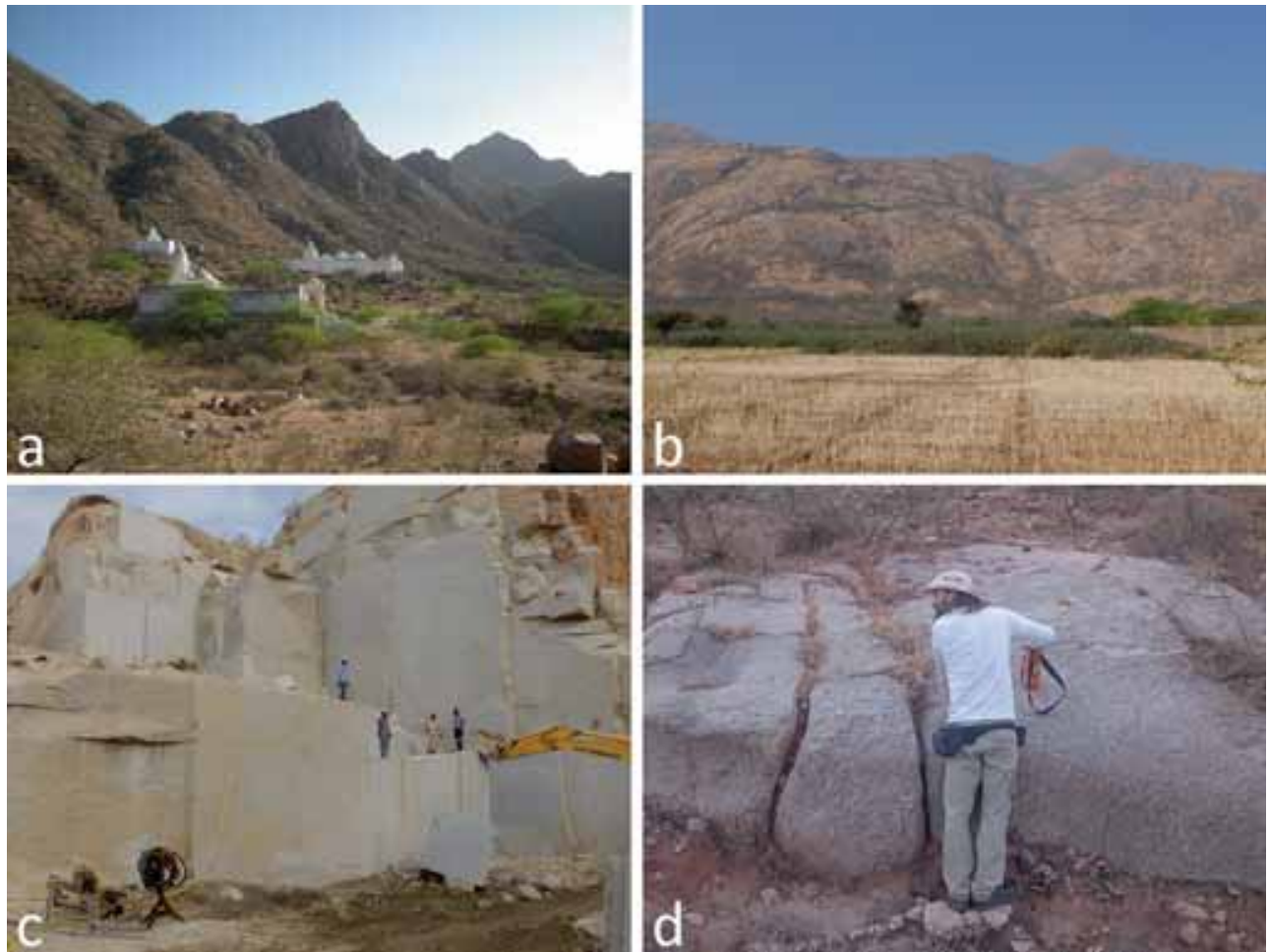

Figure 5. Field impressions from outcrops in the study area in the granitic terrain in NW India: (a) Mirpur granite; (b) Jaswantpura granite; (c) quarry in the biotite granite in the southern sector of the Jaswantpura pluton; (d) typical flat exposure of the Erinpura granite. 
this study were obtained in February 2018. In May 2018 , the calibration of the device was checked by the manufacturer of the device, GeoRadis in Brno (the Czech Republic), and found to be correct.

For interpretation of the calculated K, U and Th concentrations, possible errors and uncertainties during the data acquisition need to be taken into account. The three main sources are: (i) statistical errors due to background noise during registration of the gamma photon; (ii) calibration errors and (iii) geometrical errors if the rock exposure strongly deviates from a homogenous half-space of material. Furthermore, possible cross interferences can occur as the error components of a single element will also influence the remaining elements (Grasty et al. 1991; Radiation Solutions 2009).

\subsection{Inductively coupled plasma mass spectrometry}

Approximately $0.05 \mathrm{~g}$ of sample was accurately weighed into a Teflon beaker, and digested in 1 $\mathrm{ml} 15 \mathrm{M} \mathrm{HNO}_{3}$ and $3 \mathrm{ml} 12 \mathrm{M} \mathrm{HF}$ for $12 \mathrm{hr}$ in sealed beakers on a hotplate at $80^{\circ} \mathrm{C}$. After cooling, $0.2 \mathrm{ml}$ of $\mathrm{HClO}_{4}$ was added to the sample, and the solution evaporated to incipient dryness at $120^{\circ} \mathrm{C}$. About $2 \mathrm{ml}$ of $15 \mathrm{M} \mathrm{HNO}_{3}$ was added to the sample, and evaporated to near dryness, and this step was repeated twice before increasing the hotplate temperature to $160^{\circ} \mathrm{C}$ and fuming off excess $\mathrm{HClO}_{4}$. The sample was then redissolved in $4 \mathrm{ml} 15 \mathrm{M} \mathrm{HNO}_{3}$ and $4 \mathrm{ml} \mathrm{H} \mathrm{H}_{2} \mathrm{O}$, two drops of $12 \mathrm{M} \mathrm{HF}$ were added, and the sealed beakers were left on the hotplate at $80^{\circ} \mathrm{C}$ for $12 \mathrm{hr}$. Then, the samples were placed in an ultrasonic bath for $30 \mathrm{~min}$, before heating at $80^{\circ} \mathrm{C}$ for another $12 \mathrm{hr}$. At this stage, all samples were completely in solution. The sample solutions were then quantitatively transferred to $250 \mathrm{ml}$ High-density polyethylene (HDPE) bottles and diluted to 200 $\mathrm{g}$ with $\mathrm{MQ}$ water to obtain a final solution of $2 \% \mathrm{HNO}_{3}+0.002 \mathrm{M} \mathrm{HF}$ with a sample dilution factor of about 4000 and total dissolved solids of $250 \mu \mathrm{g} / \mathrm{ml}$. All reagents used were distilled using Teflon stills, and diluted with MQ $18.2 \Omega$ water.

Trace element measurements were carried out at the GeoZentrum Nordbayern using a Thermo Scientific X-Series 2 quadrupole inductively coupled plasma mass spectrometer. Samples were introduced into the instrument through a Cetac Aridus 2 desolvating nebuliser system in order to reduce molecular interferences. An ESI SC-2 DX FAST autosampler was used to reduce washout times between samples. The instrument was tuned using a 5 ppb solution of Be, In and U; typical sensitivity for $238 \mathrm{U}$ was $2 \times 106$ counts per second at a sample uptake rate of $50 \mu \mathrm{l} / \mathrm{min}$. The $\mathrm{Ce} / \mathrm{CeO}$ ratio was $>5000$, and thus corrections for the interference of oxides of $\mathrm{Ba}$ and the light rare-earth elements on Eu and Gd were unnecessary. Before each measurement session, the instrument was calibrated using multielement solutions covering the relevant concentration range. $\mathrm{A} \mathrm{Be}, \mathrm{In}, \mathrm{Rh}$ and $\mathrm{Bi}$ solution $(30,10,10$ and $5 \mathrm{ppb})$ was mixed with the sample online and used as the internal standard to correct for instrumental drift. Procedural blanks analysed during this work were negligible for all elements measured.

\section{Results}

\subsection{GR spectroscopic data}

The results of the gamma ray survey are compiled in table 1. GR is found to be very variable in the studied area which mainly consists of granitoids with a radiation dose ranging from 100 to 500 $\mathrm{nSv} / \mathrm{h}$. Statistical analyses reveal a rather constant median dose for the Erinpura granites of $\sim 200$ $\mathrm{nSv} / \mathrm{h}$, and more variable and higher values for the Malani granites and felsic volcanics (figure 6). By far, the highest radiation dose (up to $500 \mathrm{nSv} / \mathrm{h}$ ) is measured in the Mirpur granite, in the eastern sector of the MIS. The radiation dose in the Malani granites in the western sector (Jaswantura and Chandoor granites) has lower median values as compared to the eastern intrusions, but values are still above granitoids in the Erinpura terrain. The Malani volcanic rocks are in agreement with the Chandoor and Jaswantpura granites (table 1).

$\mathrm{U}$ and Th concentrations as well as $\mathrm{Th} / \mathrm{U}$ ratios are useful parameters in the characterisation of granitic rocks (Artemieva et al. 2017). The ternary $\mathrm{U}-\mathrm{Th}-\mathrm{K}$ diagram shows that all samples plot in the Th corner with almost constant $\mathrm{K}$ and moderate variability in Th and $\mathrm{U}$ concentrations (figure 7a). In the Th vs. U plot (figure $7 \mathrm{~b}$ ), all data fall within the field for a $\mathrm{Th} / \mathrm{U}$ ratio $>1$, but with differences in the spread and distributions pattern of individual datasets.

Th concentrations in Erinpura granites range mainly between 20 and 50 ppm, whereas U concentrations are much lower and vary mostly between 2 and $9 \mathrm{ppm}$ (figure 7c). Erinpura East granites are from an anatectic terrain east of the SFT zone 
Table 1. Compilation of GR data for Erinpura and Malani rocks in the studied area. The prefix ' $e$ ' indicates the indirect detection of uranium and thorium by means of gamma rays emitted by their decay products. $N$ represents the number of in-situ GR assays.

\begin{tabular}{|c|c|c|c|c|c|c|c|c|c|c|}
\hline & $N$ & $\begin{array}{c}\text { Dose } \\
(\mathrm{nSv} / \mathrm{h})\end{array}$ & $\begin{array}{l}\mathrm{eK} \\
(\%)\end{array}$ & Stdv & $\begin{array}{c}\mathrm{eU} \\
(\mathrm{ppm})\end{array}$ & Stdv & $\begin{array}{c}\text { eTh } \\
\text { (ppm) }\end{array}$ & Stdv & $\mathrm{Th} / \mathrm{U}$ & Stdv \\
\hline Erinpura all & 143 & 201.4 & 4.35 & 0.86 & 4.77 & 1.99 & 33.55 & 12.94 & 7.87 & 3.75 \\
\hline Erinpura E & 45 & 197.5 & 4.33 & 0.91 & 4.69 & 1.56 & 31.88 & 15.23 & 7.74 & 5.30 \\
\hline Erinpura W & 98 & 203.2 & 4.36 & 0.84 & 4.81 & 2.17 & 34.33 & 11.74 & 7.93 & 2.79 \\
\hline Malani all & 54 & 272.0 & 4.82 & 0.95 & 6.95 & 3.29 & 47.33 & 14.66 & 8.99 & 3.27 \\
\hline Volcanics & 80 & 266.7 & 4.67 & 1.04 & 6.52 & 3.07 & 47.05 & 14.23 & 8.11 & 2.8 \\
\hline Granites all & 54 & 272.0 & 5.04 & 0.75 & 7.59 & 3.53 & 47.74 & 15.39 & 6.98 & 2.00 \\
\hline Chandoor granite & 7 & 285.2 & 4.49 & 0.58 & 7.84 & 1.57 & 55.09 & 10.05 & 7.11 & 1.01 \\
\hline Jaswantpura bt-granite & 11 & 247.4 & 4.82 & 0.55 & 8.64 & 4.35 & 39.57 & 8.75 & 6.11 & 3.49 \\
\hline Jaswantpura hbl-granite & 30 & 245.5 & 5.14 & 0.81 & 6.03 & 2.07 & 42.72 & 10.25 & 7.42 & 1.45 \\
\hline Mirpur granite & 6 & 433.8 & 5.62 & 0.38 & 13.17 & 3.41 & 79.27 & 7.87 & 6.22 & 1.00 \\
\hline
\end{tabular}

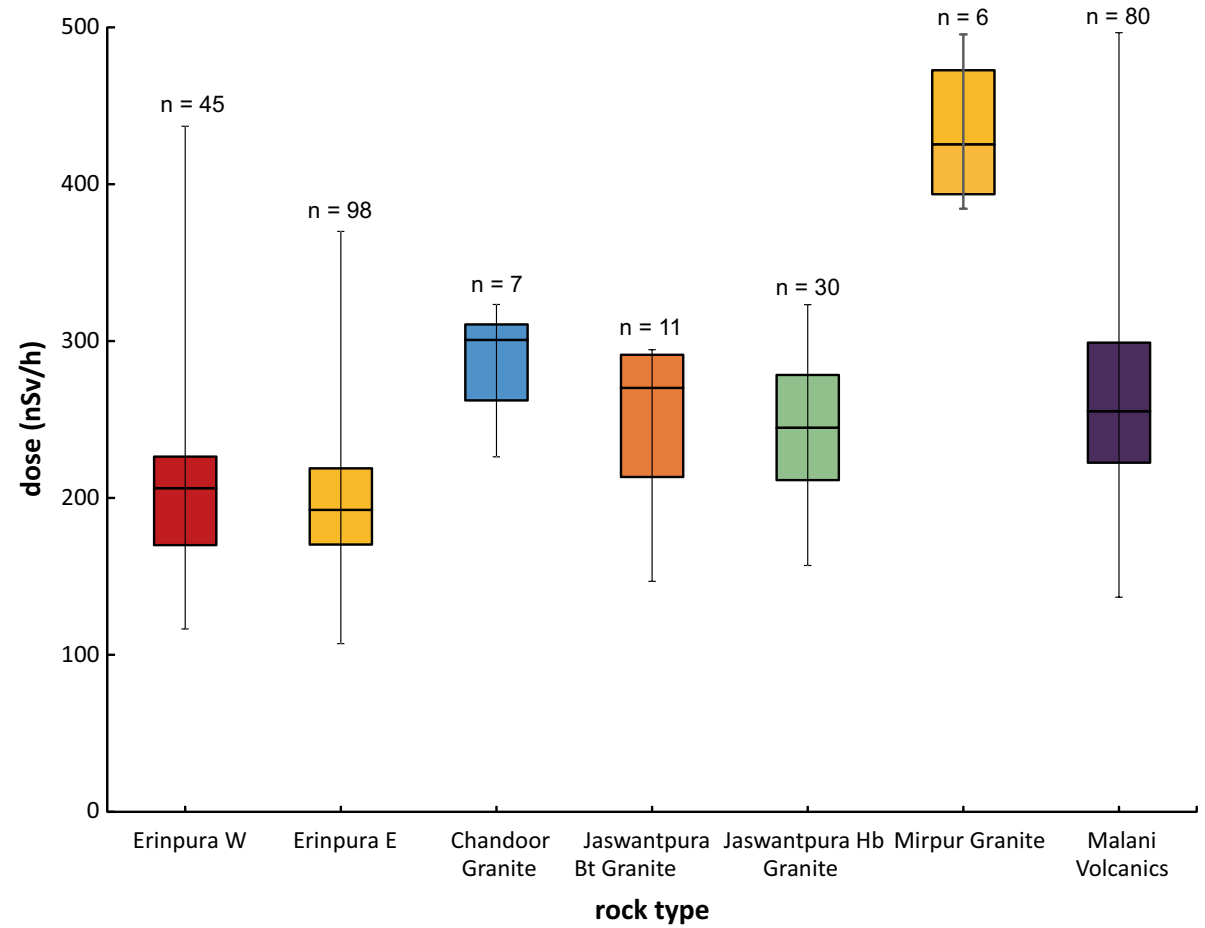

Figure 6. Box and whisker diagrams for the GR dose measured on rock surfaces of the Malani and Erinpura units.

(figure 2) and are characterised by low U concentrations of 2-8 ppm, but show a large spread in the Th content (18-85 ppm). Erinpura granites west of the SFT have a minor enhanced radioelement concentration as compared to granites in the eastern sector. They show locally enhanced U concentrations of 9-12 ppm and Th concentrations of 60-99 ppm in a fine-grained variety within the mediumto coarse-grained Erinpura granites. The Erinpura granites do not show any correlation between the $\mathrm{Th}$ and $\mathrm{U}$ concentrations and the $\mathrm{Th} / \mathrm{U}$ ratios are quite variable (figure $7 \mathrm{c}$ ).
For Malani rock types, Th concentrations vary between 20 and $100 \mathrm{ppm}$ and $\mathrm{U}$ concentrations vary between 1 and $20 \mathrm{ppm}$. The Th vs. U plot (figure $7 \mathrm{~d}$ ) displays a general trend of increasing U-concentration with increasing Th content. This holds for plutonic and for felsic varieties. Malani rocks range up to higher concentrations in all the radioelements compared to the Erinpura granitoids (table 1). Slightly higher mean values are realised in the granites as compared to the felsic dykes and volcanic flows (table 1). 

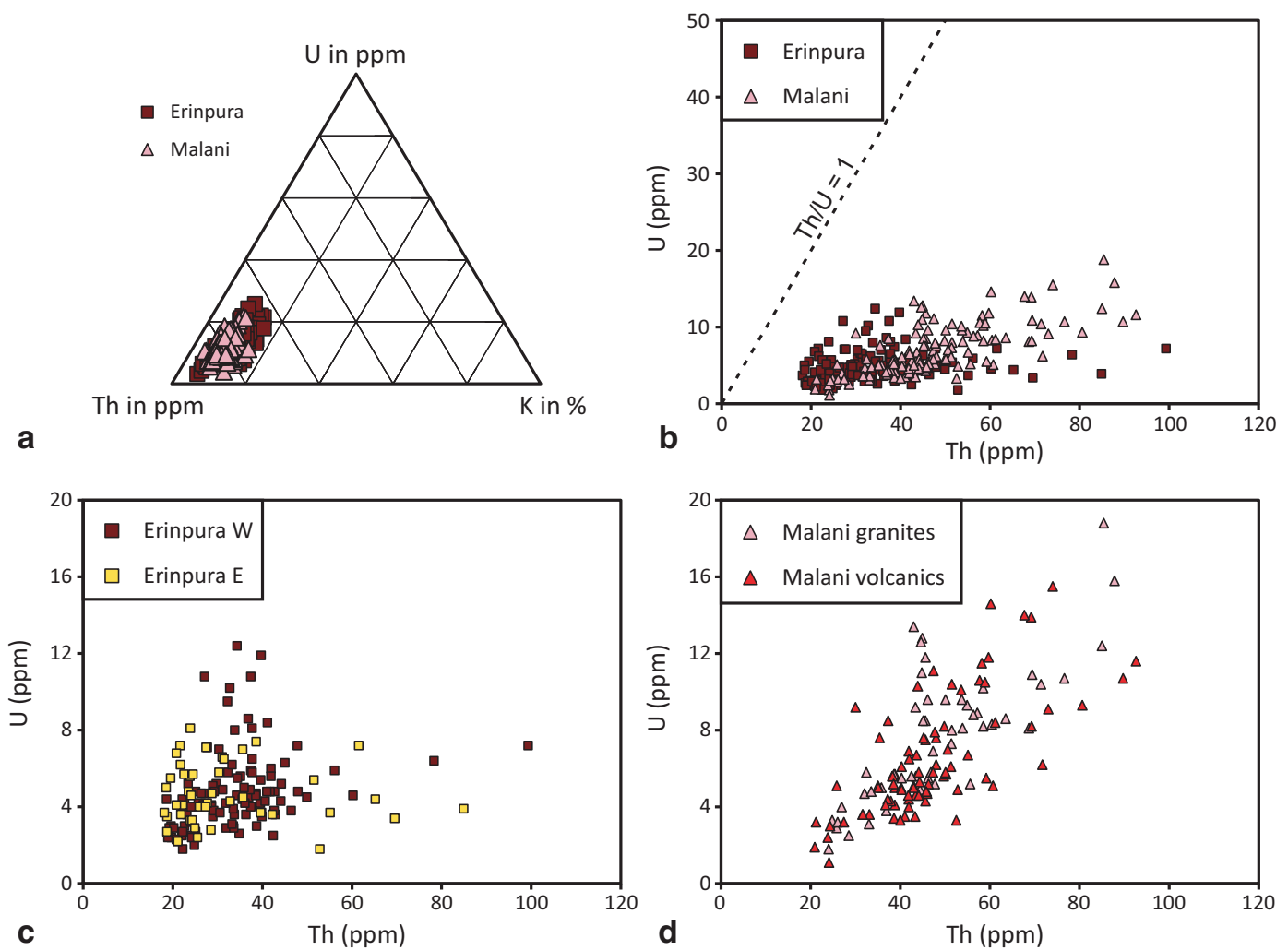

Figure 7. GR data for the Erinpura and Malani rocks: (a) ternary diagram showing K, U and Th concentrations; (b) Th vs. U diagram document of the predominance of Th over $\mathrm{U}$ for all measurements; (c) Th vs. U plots for the Erinpura granite E and W of the SFT (see figure 2); (d) Th vs. U plots for the Malani granite and volcanics and felsic dykes, respectively.

Table 2. Comparison of $U$ and Th concentrations determined by in-situ measurements (GR) and geochemical analyses (ICP$M S)$ for the sample sites in Erinpura and Malani rock units. For further comparison, a sample from the granite-gneisses west of the Jaswantpura granites, named as 'basement' is considered. For coordinates and individual GR measurements within the sample locations, see supplementary material.

\begin{tabular}{|c|c|c|c|c|c|c|c|c|c|}
\hline \multicolumn{5}{|c|}{ GR } & \multicolumn{5}{|c|}{ ICP-MS } \\
\hline Location & $N$ & $\mathrm{eU}(\mathrm{ppm})$ & eTh (ppm) & $\mathrm{Th} / \mathrm{U}$ & Sample & $\mathrm{U}(\mathrm{ppm})$ & Th (ppm) & $\mathrm{Th} / \mathrm{U}$ & \\
\hline GP 4b & 4 & 2.58 & 23.88 & 9.27 & JW-18-3aI & 1.45 & 16.97 & 11.70 & Erinpura \\
\hline GP 4b & 4 & 2.58 & 23.88 & 9.27 & JW-18-3aII & 1.25 & 15.65 & 12.54 & Erinpura \\
\hline GP 8 & 3 & 4.33 & 26.47 & 6.11 & JW-18-6 & 3.53 & 22.93 & 6.49 & Erinpura \\
\hline GP 9 & 4 & 3.90 & 41.20 & 10.56 & JW-18-7 & 4.44 & 39.57 & 8.91 & Erinpura \\
\hline GP 2 & 8 & 10.98 & 44.63 & 4.07 & JW-18-1 & 8.78 & 25.78 & 2.94 & Malani \\
\hline GP 5b & 2 & 4.20 & 40.80 & 9.71 & JW-18-4a & 5.18 & 36.47 & 7.05 & Malani \\
\hline GP 5e & 6 & 5.32 & 40.20 & 7.56 & JW-18-5c & 5.81 & 35.81 & 6.16 & Malani \\
\hline GP 17 & 1 & 4.80 & 33.50 & 6.98 & JW-18-16a & 4.76 & 31.24 & 6.57 & Malani \\
\hline GP 17 & 1 & 10.20 & 58.50 & 5.74 & JW-18-16b & 11.08 & 47.46 & 4.28 & Malani \\
\hline GP 18 & 2 & 7.65 & 51.45 & 6.73 & JW-18-17 & 9.54 & 45.52 & 4.77 & Malani \\
\hline GP 64 & 1 & 5.50 & 46.20 & 8.40 & JW-18-46 & 4.64 & 32.7 & 7.05 & Malani \\
\hline GP 79b & 3 & 2.03 & 11.80 & 5.80 & JW-18-59a & 2.21 & 8.10 & 3.66 & Basement \\
\hline
\end{tabular}

\subsection{Comparison of $G R$ and geochemical analysis}

$\mathrm{U}$ and Th concentrations of samples from the same outcrops were measured by GR and ICP-MS, in order to compare both methods (table 2 and figure 8). The measurements were taken out on the same rocks as close together as possible, but because of the different sampling strategy, one to several metres apart. For location and coordinates, refer the supplementary material. Thus, when comparing both methods, the inhomogeneity of the rocks in the field has to be taken into account. We 

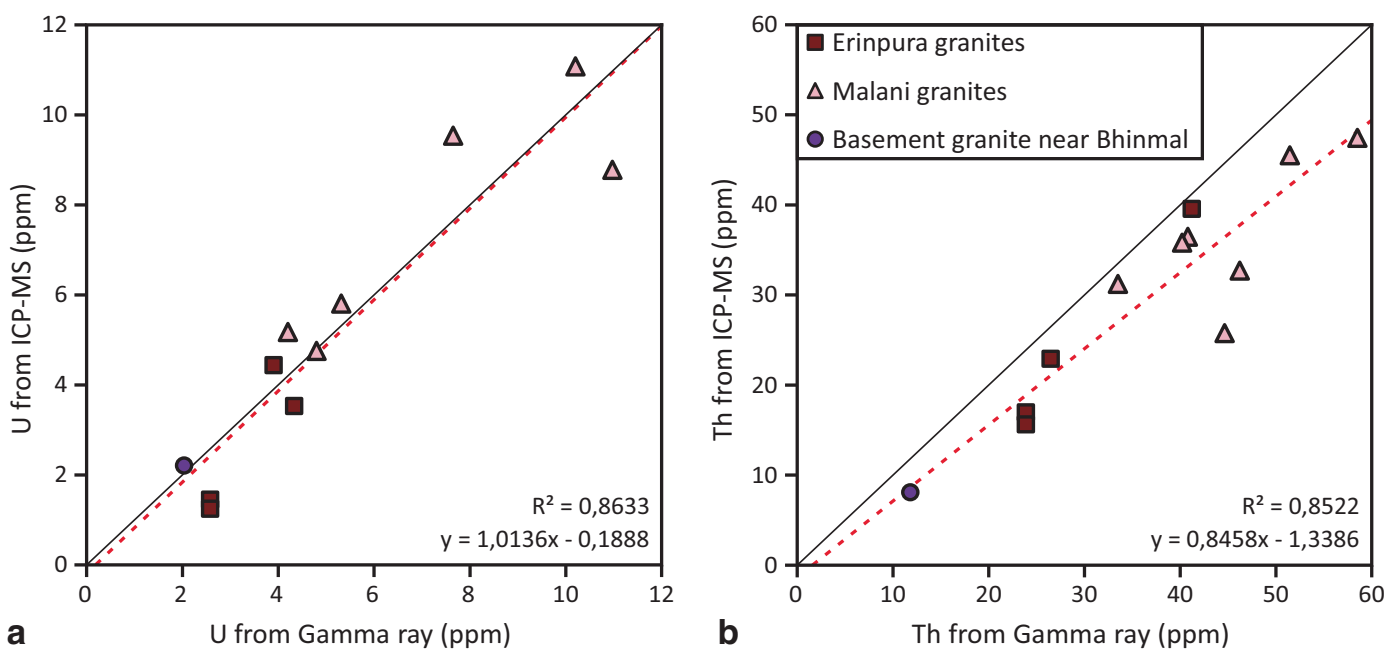

Figure 8. Correlation diagram for (a) uranium and (b) thorium.

therefore measured the $\mathrm{U}$ and Th concentrations by GR in several outcrops four to eight times, always a few metres apart from each other. The accuracy for $\mathrm{U}$ concentrations varied between $10 \%$ and $22 \%$ and for Th concentrations between $5 \%$ and $33 \%$ (for absolute concentrations, see data compilation in the supplementary material). The precision of the GR method for $\mathrm{U}$ at this concentration level is $\sim 1.5 \mathrm{ppm}$ and for Th, $2.5 \mathrm{ppm}$. The precision of the $\mathrm{U}$ and Th measurements by ICP-MS are $\sim 5 \%$ for granites. However, the accuracy of $\mathrm{U}$ and Th concentrations in granites measured by ICP-MS may be lower, because zircon and monazite, the main carriers of $\mathrm{U}$ and $\mathrm{Th}$ in these rocks, are difficult to always be dissolved completely, even with hydrofluoric acid.

Taking all this into account, when comparing GR and ICP-MS data, the U concentrations are well within the error of the uncertainties and measurements. The Th concentrations are just about within the error, but are constantly lower for the ICP-MS measurements. This might be due to monazite that is not completely dissolved during the sample-dissolving procedure.

Given that the two methods have completely different sampling techniques, the agreement is very good, considering the uncertainties of the two methods.

\section{Discussion and interpretation}

\subsection{Th and $U$ concentrations}

Even within rock types, Th and U concentrations are commonly quite broad. The differences are commonly greater than the average differences between the various igneous rock types (Adams et al. 1959). However, even though U and Th concentrations vary widely in different rocks types (Vilà et al. 2010), the $\mathrm{Th} / \mathrm{U}$ ratios in granitoids are rather constant (Wasserburg 1964; Vilà et al. 2010). The recently established database on worldwide granites (GRANITE2017, Artemieva et al. 2017 ) reports $14.8 \pm 13.2 \mathrm{ppm}$ as the mean Th content and $3.93 \pm 3.27 \mathrm{ppm}$ as the mean $\mathrm{U}$ content in granites. Th and U concentrations in Erinpura $\left(\mathrm{Th}_{\text {mean }} 33.55 \pm 12.4, \mathrm{U}_{\text {mean }} 4.77 \pm 1.99\right)$ as well as in Malani rocks $\left(\mathrm{Th}_{\text {mean }} 47.33 \pm 14.66, \mathrm{U}_{\text {mean }}\right.$ $6.95 \pm 3.29)$ are considerable above this average.

Th and $\mathrm{U}$ concentrations as well as $\mathrm{Th} / \mathrm{U}$ ratios are quite variable in the studied granitoids (table 1 and figure 7 ) and the magmatic suites show significant differences in element concentrations and $\mathrm{Th} / \mathrm{U}$ ratios. The Malani granites range up to higher Th and U concentrations compared to Erinpura granites, implying that they are partly more differentiated. Typical for Malani rocks are constant $\mathrm{Th} / \mathrm{U}$ ratios with a regular increase in the total abundance (figure $7 d$ ). Such a pattern defines a typical trend of fractional crystallisation in felsic magmas. The correlation of Th and $\mathrm{U}$ concentrations in figure $7(\mathrm{~d})$ therefore indicates that secondary fluid mobilisation has not played a major role in the Malani granites, as fluid mobilisation can change the concentration of $\mathrm{U}$, but does not affect the concentration of Th. This is because $\mathrm{U}$ is far more mobile because of its increased solubility at higher oxidation states, whereas Th has only one valence state and remains inside the lattice sites of the minerals. Secondary U mobilisation along localised fault zones has been reported for the 

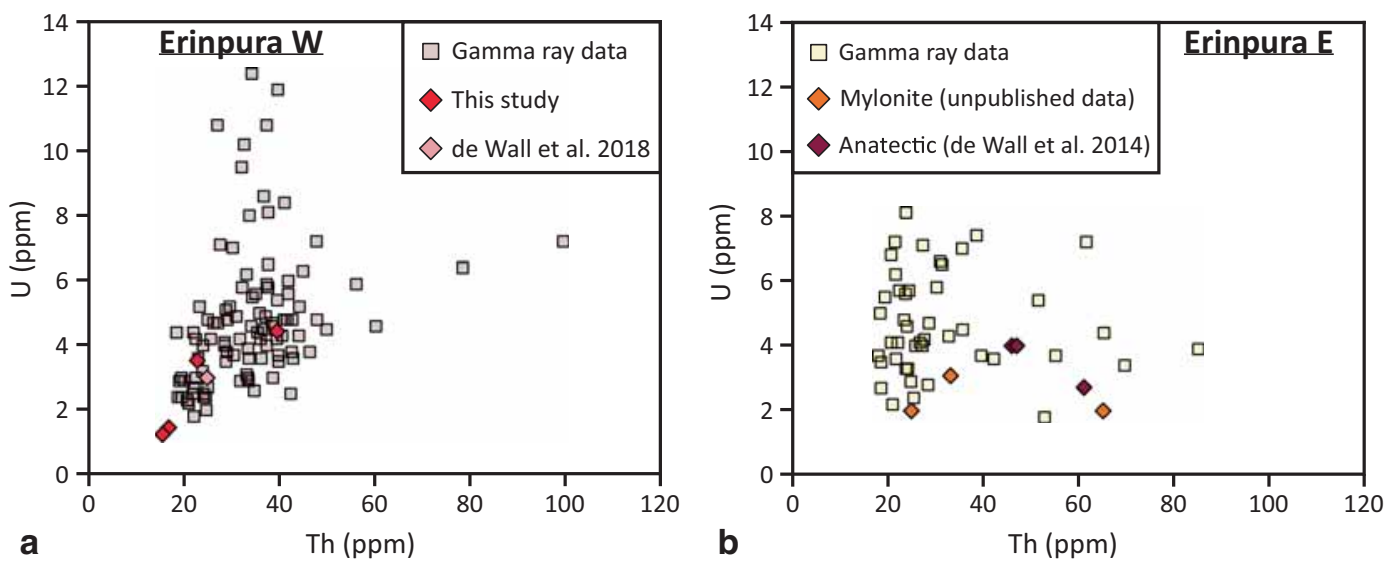

Figure 9. Comparison of GR data with geochemical data, individual geochemical data from different sources are shown as diamonds, for reference, see legend.

Sindreth setting as part of the MIS (Scharfenberg et al. 2015).

$\mathrm{Th} / \mathrm{U}$ ratios in all the studied granites are higher than the average of the upper crust (3.8 ppm, Taylor and McLennan 1985), but are not unusual for lower and middle continental crust and granites (Maden and Akaryali 2015). In general, the high Th concentrations can be explained by the presence of monazites in the granites. High Th values are recorded for the Erinpura granites east of the SFT. These rock types also show high $\mathrm{Th} / \mathrm{U}$ ratios $(>20)$ that are calculated for melanocratic restites. Erinpura West granitoids have generally lower Th concentrations, only two measurements in the fine-grained Erinpura variety show values $>60$ ppm, in correlation with an increase in $U$ content. This could indicate pulses of higher fractionated magma as late Erinpura intrusions. However, for petrogenetic implications, more detailed geochemical and isotopic analyses are required which are currently under work. Some of the Jaswantpura biotite granites show high $\mathrm{U}$ concentrations up to $13 \mathrm{ppm}$. As the Th values are not elevated (45 ppm), the high uranium concentrations can be explained by the general high $\mathrm{U} / \mathrm{Th}$ ratios in biotites.

It has been discussed in the previous section that $\mathrm{U}$ and Th data from in-situ GR measurements and geochemical analyses are in good agreement, which allows the compilation of geochemical and gamma spectroscopic data sets. This allows the inclusion of previous $\mathrm{U}$ and Th analytical data and the comparison with other prominent granite intrusions in the vicinity of the study area. Of special interest is the Jalor granite (for location, see figure 1) considered as the type locality for the pink MIS granites (Eby and Kochhar 1990; Carter 2005). The Mt Abu batholith is the largest Neoproterozoic intrusion in this region and has been the focus of previous geochemical and geochronological studies (Singh 2007; de Wall et al. 2012; Ashwal et al. 2013).

\subsubsection{Erinpura granites}

So far, only a few geochemical data sets have been available which include $\mathrm{Th}$ and $\mathrm{U}$ analyses of the Erinpura granites. de Wall et al. (2014) have published data on the anatectic and mylonitic Erinpura granites. Furthermore, a single analysis of mylonitic rocks from the Daba shear zone (unpublished data) is illustrated in figure 9 . There are no $\mathrm{U}$ and Th analyses for the Erinpura granites west of the SFT, except from one single analysis recorded by de Wall et al. (2018).

\subsubsection{Malani granites}

U-Th data for the Jalor and Mt Abu granites support the general trend line for a simultaneously increase in the element concentration in Malani granites (figure 10). The Jalor granite shows Th values $<40 \mathrm{ppm}$ and $\mathrm{U}<8 \mathrm{ppm}$ and thus strengthens the field for Malani granites with relatively low radioelement concentration. Compared to the Jalor and Jaswantpura granites, Mt Abu shows a wide range of radioelement concentrations in agreement with the model of emplacement of several magma batches to form this large $\left(\sim 125 \mathrm{~km}^{2}\right)$ pluton (de Wall et al. 2012; Ashwal et al. 2013). The extremely high $\mathrm{Th}$ and $\mathrm{U}$ concentrations in the Mirpur 


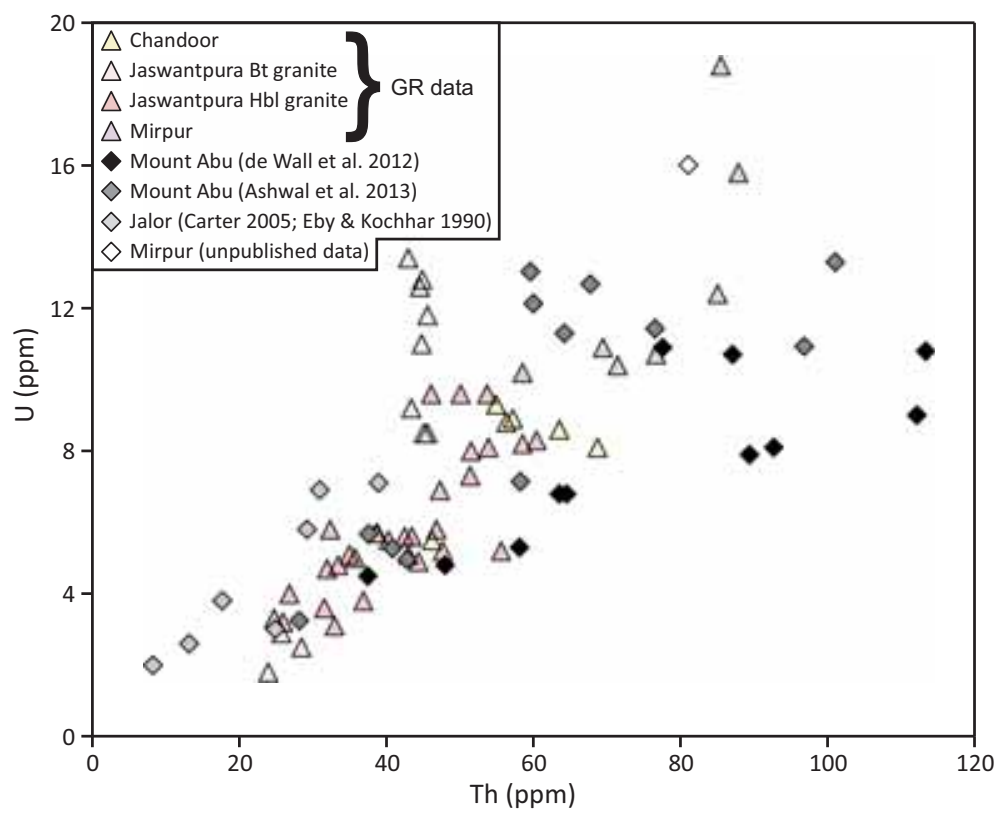

Figure 10. U and Th concentrations in Malani granites, comparison of GR data (triangles, this study) with geochemical data (circles), for references, see legend.

granite recorded by GR measurements are confirmed by geochemical analyses.

From the compilation shown in figure 10, some findings can be useful for further petrogenetic studies. High radioelement concentration is recorded for MIS granites in the eastern sector (Mirpur, Mt Abu) while prominent granites in the western sector (Jaswantpura, Jalor) tend to lower values. By combining GR and geochemical data, a linear trend line $\left(\mathrm{Th}=0.14 * U, R^{2}=0.6\right)$ can be defined. From this trend, a mean Th-U ratio of 7.14 for the peraluminous to the metaluminous A-type Malani granites can be inferred, which is in good agreement with the $\mathrm{Th} / \mathrm{U}$ ratio of 7.1 , solely from the GR measurements (table 1). The Malani felsic dykes and flows (Malani volcanics in table 1) show a slightly higher $\mathrm{Th} / \mathrm{U}$ ratio of 8.1. In general, $\mathrm{Th}$ and $\mathrm{U}$ concentrations are quite variable in A-type and I-type granites (Artemieva et al. 2017). However, the Malani suite shows a linear trend of $\mathrm{Th} v s$. $\mathrm{U}$ and quite constant $\mathrm{Th} / \mathrm{U}$ ratios, which might be due to fractional crystallisation. The correlation indicates that the source of the felsic MIS has been rather homogeneous. The lower values in the west compared to the east could infer that either the melting degree of the source has been higher in the west or the degree of fractional crystallisation has been higher in the east or both. In order to get more petrogenetical constraints, detailed geochemical and isotopic analyses are required, which are currently under work.

\subsection{GR dose}

For the risk assessment and calculation of the annual effective radiation dose, further studies and calculations on indoor and outdoor radiation exposure doses would be needed (e.g., Grasty and LaMarre 2004; Puccini et al. 2014). Knowledge of background radiation and definition of regional baselines are crucial for (i) identifying areas or rock types with high natural radiation background to reduce health risks and (ii) for the separation of contaminations from natural background radiation in emergency cases (Marsac et al. 2016).

So far, the emanation of radon and thoron gas from Neoproterozoic rocks with high radioelement concentration has been studied in detail in the Tosham area as part of the Malani terrain in NW India (Singh et al. 2015) and lies within the safe limits as recommended by the UNSCEAR (2000). However, radon gas can concentrate in soil and ground water and needs to be considered for the safety of populations in regions with high radioelement concentration (Duggal et al. 2014; Mittal et al. 2016). Therefore, the measured high radioelement concentrations in granitoids studied here await further scientific attention. 


\section{Conclusions}

- High correlation between in-situ GR measurements and geochemical data underlines the suitability and precision of the GR method for reliable determination of $\mathrm{U}$ and $\mathrm{Th}$ concentration during field survey. GR data can therefore support the sampling of detailed geochemical and petrogenetic research projects.

- Erinpura and Malani granites have relatively high Th and U concentrations. A linear increase of $\mathrm{U}$ and $\mathrm{Th}$ is observed within larger plutons e.g., in the Jaswantpura granites and the Mt. Abu batholith. Th-U ratios are quite constant for all Malani granites $(\mathrm{Th} / \mathrm{U}=7)$ and infer a rather homogeneous source. An average Th-U ratio of 8 is determined for Malani felsic dykes and rhyolitic flows.

- Part of the Malani felsic rocks show extremely high $\mathrm{U}$ and Th concentration, which points to a high degree of fractionation of the magma. In addition, the data suggests a positive Th and $\mathrm{U}$ concentration trend from the west to the east which needs further attention during geochemical and isotopic studies.

- Erinpura granites do not have as high Th and U concentrations compared to Malani granites and are thus probably less differentiated. The eastern and western Erinpura terrain show different Th and U characteristics. In the western part, a linear correlation of $\mathrm{Th} v s$. $\mathrm{U}$ is still visible, in the eastern part, the pattern is disturbed due to younger anatectic processes in this region.

\section{Acknowledgements}

We thank Marcel Regelous for the support with the geochemical measurements and Tom Brunclik of Georadis, Brno for the technical support with the gamma spectrometer and the hospitality during the trip to Brno in May 2018. We also thank Stefan Gleissner, Hendrik Raabe and Michel Bestmann for the support with the fieldwork in 2018, with the sample preparation and the assistance with some of the figures in this study. We also thank the two anonymous reviewers for their valuable comments and suggestions to improve the manuscript.

\section{References}

Adams A S, Osmond J K and Rogers J J W 1959 The geochemistry of thorium and uranium; Phys. Chem. Earth 3 $298-348$
Al-Jarallah M 2001 Radon exhalation from granites used in Saudi Arabia; J. Environ. Radioact. 53 91-98.

Archibald D B, Collins A S, Foden J D, Payne J L, Holden P, Razakamanana T, De Waele B, Thomas R J and Pitfield P E J 2016 Genesis of the tonian imorona-itsindro magmatic suite in central Madagascar: Insights from U-Pb, oxygen and hafnium isotopes in zircon; Precamb. Res. 281312 337.

Arora D, Pant N, Fareeduddin, Sharma S, Ram R and Sadiq M 2017 Inferring a Neoproterozoic orogeny preceding the Rodinia break-up in the Sirohi Group, NW India; Geol. Soc. London, Spec. Publ. 457 319-338.

Artemieva I A, Thybo H, Jakobson K, Sorensen N K and Nielsen L S K 2017 Heat production in granitic rocks: Global analysis based on a new data compilations GRANITE2017; Earth-Sci. Rev. 172 1-26.

Ashwal L D, Solanki A M, Pandit M K, Corfu F, Hendriks B W H, Burke K and Torsvik T H 2013 Geochronology and geochemistry of Neoproterozoic Mt. Abu Granitoids, NW India: Regional correlation and implications for Rodinia paleogeography; Precamb. Res. 236 265-281.

Bea F, Monero P and Zinger T 2003 The nature, origin, and thermal influence of the granite source layer of Central Iberia; J. Geol. 111 579-595.

Beamish D and Busby J 2016 The Cornubian geothermal province: Heat production and flow in SW England: Estimates from boreholes and airborne gamma-ray measurements; Geoth. Energ. 4 4, https://doi.org/10.1186/ s40517-016-0046-8.

Bhushan S K 2000 Malani rhyolites - A review; Gondwana Res. 3 65-77.

Carter L 2005 Granitic and rhyolitic magmatism: Constraints on continental reconstruction from geochemistry, geochronology and paleomagnetism; Master's Thesis, University of Johannesburg, $54 \mathrm{p}$.

Coulson A L 1933 The geology of Sirohi State, Rajputana; Geol. Soc. India Mem. LXIII, Part 1, 166p.

Deb M, Thorpe R I, Krstic D, Corfu F and Davis D W 2001 Zircon $\mathrm{U}-\mathrm{Pb}$ and galena $\mathrm{Pb}$ isotope evidence for an approximate $1.0 \mathrm{Ga}$ terrain constituting the western margin of the Aravalli-Delhi orogenic belt, northwestern India; Precamb. Res. 108 195-213.

de Wall H, Schöbel S, Pandit M K, Sharma K K and Just J 2010 A record of ductile syn-intrusional fabrics to post solidification cataclasis: Magnetic fabric analyses of Neoproterozoic Mirpur and Mt. Abu Granitoids, NW India; J. Geol. Soc. India 75 239-253.

de Wall H, Pandit M K, Dotzler R and Just J 2012 Cryogenian transpression and granite intrusion along the western margin of Rodinia (Mt. Abu region): Magnetic fabric and geochemical inferences on Neoproterozoic geodynamics of the NW Indian block; Tectonophys. 554-557 143-158.

de Wall H, Pandit M K, Sharma K K, Schöbel S and Just J 2014 Deformation and granite intrusion in the Sirohi area, SW Rajasthan - Constraints on Cryogenian to PanAfrican crustal dynamics of NW India; Precamb. Res. 254 $1-18$.

de Wall H, Pandit M K, Donhauser I, Schöbel S, Wang W and Sharma K K 2018 Evolution and tectonic setting of the Malani-Nagarparkar igneous suite: A neoproterozoic silicic-dominated large igneous province in NW India-SE Pakistan; J. Asian Earth Sci. 160 136-158. 
Dharma Rao C V, Santosh M and Kim S W 2012 Cryogenian volcanic arc in the NW Indian shield: Zircon SHRIMP $\mathrm{U}-\mathrm{Pb}$ geochronology of felsic tuffs and implications for Gondwana assembly; Gondwana Res. 22 36-53.

Duggal V, Rani A and Mehra R 2014 Measurement of soilgas radon in some areas of northern Rajasthan, India; $J$. Earth Syst. Sci. 123 1241-1247.

Eby G N and Kochhar N 1990 Geochemistry and petrogenesis of the Malani Igneous Suite, northern India; J. Geol. Soc. India 36 109-130.

Fernàndez M, Marzán I, Correia A and Ramalho E 1998 Heat flow, heat production, and lithospheric thermal regime in the Iberian peninsula; Tectonophys. 291 29-53.

Förster A and Förster H-J 2000 Crustal composition and mantle heat flow: Implications from surface heat flow and radiogenic heat production in the Variscan Erzgebirge (Germany); J. Geophys. Res. 105 27,917-27,938.

Grasty R L and LaMarre J R 2004 The annual effective dose from natural sources of ionising radiation in Canada; Radiat. Prot. Dosim. 108 215-226.

Grasty R L, Holman P B and Blanchard Y B 1991 Transportable calibration pads for ground and airborne gammaray spectrometers; Geol. Surv. Canada, Paper 90-23 $25 p$.

Gregory L C, Meert J G, Bingen B H, Pandit M K and Torsvik T H 2009 Paleomagnetic and geochronological study of the Malani Igneous Suite, NW India: Implications for the configuration of Rodinia and the assembly of Gondwana; Precamb. Res. 170 13-26.

Gupta S N, Arora Y K, Mathur R K, Iqballaddin Prasad B, Sahai T N and Sharma S B 1997 The precambrian geology of the Aravalli Region, Southern Rajasthan and Northeastern Gujarat; Geol. Surv. Ind. Memoir. 123262.

Heron A M 1953 Geology of Central Rajputana; Geol. Surv. Ind. Memoir. 79339.

IAEA 2004 Radiation, people and the environment; International Atomic Energy Agency, Austria, 80p.

Jan M Q, Laghari A, Agheem M H and Anjum S 2014 Geology and petrography of the Nagar Parker igneous complex, southeastern Sindh: The Dinsi body; J. Him. Earth Sci. 47 1-14.

Jan M Q, Agheem M H, Laghari A and Anjum S 2017 Geology and petrography of the Nagar Parkar Igneous Complex, southeastern Sindh, Pakistan: The Kharsar body; J. Geol Soc. India 89 91-98.

Jaupart C and Mareschal J C 2003 Constraints on crustal heat production from heat flow data; In: Treatise on geochemistry (eds) Holland H D and Turekian K K, Vol. 4, The crust (ed.) Rudnick R L, Elsevier-Pergamon, Oxford, pp. 65-84.

Just J, Schulz B, de Wall H, Jourdan F and Pandit M K 2011 Monazite CHIME/EPMA dating of granitoid deformation: Implications for neoproterozoic tectono-thermal evolution of NW India; Gondwana Res. 19 402-412.

Khan T, Maruta M, Rehman H U, Zafar M and Ozawa H 2012 Nagarparkar granites showing Rodinia remnants in the southeastern part of Pakistan; J. Asian Earth Sci. 59 $39-51$.

Konopelko D, Biske G, Seltmann R, Eklund O and Belyatsky B 2007 Hercynian post-collisional A-type granites of the Kokshaal Range, Southern Tien Shan, Kyrgyzstan; Lithos 97 140-160.
Li W X, Li X H and Li Z H 2010 Ca. 850 Ma bimodal volcanic rocks in northeastern Jiangxi Provence, South China: Initial extension during the breakup of Rodinia?; Am. J. Sci. 310 951-980.

Maden N and Akaryali E 2015 A review for genesis of continental arc magmas: $\mathrm{U}, \mathrm{Th}, \mathrm{K}$ and radiogenic heat production data from the Gümüşhane Pluton in the Eastern Pontides (NE Türkiye); Tectonophys. 664 225-243.

Maheshwari A, Garhia S S, Sial A N, Ferreira V P, Dwivedi V and Chittora V K 2002 Geology and geochemistry of granites around Jaswantpura, Jalor District, Southwestern Rajasthan, India; Gondwana Res. 5 373-379.

Marchalland C P and Fairbridge R W 1999 Encyclopedia of geochemistry; Kluwer Academic Press, Dordrecht, Boston.

Marsac K E, Burnley P C, Adcock C T, Haber D A, Malchow R L and Hausrath E M 2016 Modeling background radiation using geochemical data: A case study in and around Cameron, Arizona; J. Environ. Radioact. 165 68-85.

McCay A, Harley T, Younger P, Sanderson D and Cresswell A 2014 Gamma-ray spectrometry in geothermal exploration: State of the art techniques; Energies 74757 4780 .

McLaren S, Sandiford M and Hand M 1999 High radiogenic heat-producing granites and metamorphism - An example from the western Mount Isa inlier, Australia; Geology 27(8) 679-682.

McLennan S M 2001 Relationship between the trace element composition of sedimentary rocks and upper continental crust; Geochem. Geophys. Geosyst. 2(4), https://doi.org/ 10.1029/2000GC000109.

Menager M T, Heath M J, Ivanovich M, Montjotin C, Barillon C R, Camp J and Hasler S E 1993 Migration of uranium from uranium-mineralised fractures into the rock matrix in granite: Implications for radionuclide transport around a radioactive waste repository; Radiochim. Acta 66(67) 47-83.

Menon R, Kumar P S, Reddy G K and Srinivasan R 2003 Radiogenic heat production of Late Archaean Bundelkhand granite and some Proterozoic gneisses and granitoids of central India; Curr. Sci. 85 634-638.

Mittal S, Rani A and Mehra R 2016 Estimation of radon concentration in soil and groundwater samples of Northern Rajasthan, India; J. Radiat. Res. Appl. Sci. 9 125-130.

Mohanty A K, Sengupta D, Das S K, Saha S K and Van K V 2004 Natural radioactivity and radiation exposure in the high background area at Chhatarpur beach placer deposit of Orissa, India; J. Environ. Radioact. 75(1) 15-33.

Pareek H S 1984 Pre-Quaternary geology and mineral resources of Northwestern Rajasthan; Geol. Surv. Ind. Memoir. 11595.

Patra I, Srinivas D, Tripathi S, Patel A K, Ramesh Babu V, Raju B V S N and Chaturvedi K 2016 Airborne gammaray spectrometric data in geological mapping - A case study from parts of Shillong Basin, Meghalaya; J. Geophys. 173 173-178.

Puccini A, Xhisha G, Cuccuru S, Oggiano G, Xhixha M, Mantovani F, Alvarez C R and Casini L 2014 Radiological characterization of granitoid outcrops and dimension stones of the Variscan Corsica-Sardinia Batholith; Environ. Earth Sci. 71 393-405.

Purohit R, Papineau D, Kröner A, Sharma K K and Roy A B 2012 Carbon isotope geochemistry and geochronological 
constraints of the Neoproterozoic Sirohi Group from northwest India; Precamb. Res. 220-221 80-90.

Radiation Solutions 2009 Spectrum stabilization and calibration for the RSI RS-125 and RS-230 handheld spectrometers: RSI technical note; \# - RSG 703Mississauga (Radiation Solutions), Technical Note, unpublished, 6p.

Rudnick R L and Fountain D M 1995 Nature and composition of the continental crust: A lower crustal perspective; Rev. Geophys. 33(3) 267-309.

Rudnick R L, McDonough W and O'Conell R J 1998 Thermal structure, thickness and composition of continental lithosphere; Chem. Geol. 145 395-411.

Scharfenberg L and de Wall H 2016 Natural gamma radiation of granites in the Oberpfalz (NE Bavaria, Germany)comparison of aerogeophysical and in situ gamma spectroscopic measurements; Geol. Bl. Nordost-Bayern Angrenzende Geb. 66 205-227.

Scharfenberg L, de Wall H, Schöbel S, Minor A, Maurer M, Pandit M K and Sharma K K 2015 In-situ gamma radiation measurements in the Neoproterozoic rocks of Sirohi region, NW India; J. Earth Syst. Sci. 124 1223-1234.

Scharfenberg L, de Wall H and Bauer W 2016 In-situ gamma radiation measurements on Variscan granites and inferred radiogenic heat production, Fichtelgebirge, Germany; Z. Dtsch. Ges. Geowiss. 167 19-32.

Schöbel S, Sharma K K, Hörbrand T, Böhm T, Donhauser I and de Wall H 2017 Continental rift-setting and evolution of Neoproterozoic Sindreth Basin in NWIndia; J. Earth Syst. Sci. 126 90, https://doi.org/10. 1007/s12040-017-0855-6.

Sharaf M, Mansy M, El Sayed A and Abbas E 1999 Natural radioactivity and radon exhalation rates in building materials used in Egypt; Radiat. Meas. 31 491-495.

Sharma K K 2004 The Neoproterozoic Malani magmatism of the northwestern Indian shield: Implications for crustbuilding processes; J. Earth Syst. Sci. 113 795-807.

Singh B N 2007 Petrology and geochemistry of Mt. Abu granites, southeastern Rajasthan; J. Geol. Soc. India 69 $247-252$.

Singh L S and Vallinayagam G 2012 High heat producing volcano-plutonic rocks of the Siner area, Malani Igneous Suite, Western Rajasthan, India; Int. J. Geosci. 3 11371141.

Singh S, Singh P, Singh S, Sahoo B K, Sapra B K and Bajwa B S 2015 A study of indoor radon, thoron and their progeny measurement in Tosham region Haryana, India; J. Radiat. Res. Appl. Sci. 8 226-233.
Smethurst M A, Strand T, Sundal A V and Rudjord A L 2008 Large-scale radon hazard evaluation in the Oslofjord region of Norway utilizing indoor radon concentrations, airborne gamma ray spectrometry and geological mapping; Sci. Total Environ. 407 379-393.

Solanki A 2011 A petrographic, geochemical and geochronological investigation of deformed granodiorites from SW Rajasthan: Neoproterozoic age of formation and evidence for Pan-African imprint; Masters Dissertation, University of Witwatersrand, South Africa, 216p.

Stoulos S, Manolopoulou M and Papastefanou C 2003 Assessment of natural radiation exposure and radon exhalation from building material in Greece; J. Environ. Radioact. 69 225-240.

Taylor S R and McLennan S M 1985 The continental crust: Its evolution and composition; Rev. Geophys. 33 241265.

Van Schmus W R 1995 Natural radioactivity of the crust and mantle; In: Global earth physics. A handbook of physical constants; AGU Reference Shelf, Vol. 1, pp. 283-293.

Vilà M, Fernández M and Jiménez-Munt I 2010 Radiogenic heat production variability of some common lithological groups and its significance to lithospheric thermal modeling; Tectonophys. 490 152-164.

Wang Q, Wyman D A, Li Z X, Bao Z W, Zhao Z H, Wang Y X, Jiang P, Yang Y H and Chen L L 2010 Petrology, geochronology and geochemistry of ca. 780Ma A-type granites in South China: Petrogenesis and implications for crustal growth during the breakup of the supercontinent Rodinia; Precamb. Res. 178 185-208.

Wang W, Pandit M K, Zhao J H, Chen W T and Zheng J P 2018 Slab break-off triggered lithosphere - Asthenosphere interaction at a convergent margin: The neoproterozoic bimodal magmatism in NW India; Lithos 296-299 281296.

Wark D A and Miller C F 1993 Accessory mineral behavior during differentiation of a granite suite: Monazite, xenotime and zircon of the sweetwater wash pluton, southeastern California, U.S.A; Chem. Geol. 110 49-67.

Wasserburg G J 1964 Pb-U-Th evolution models for homogeneous systems with transport; Trans. Am. Geophys. Union 45(1) 111.

Wedepohl K H 1995 The composition of the continental crust; Geochim. Cosmochim. Acta 59(7) 1217-1232.

Zhang S B and Zheng Y F 2013 Formation and evolution of Precambrian continental lithosphere in South China; Gondwana Res. 23 1241-1260. 